\title{
Pengaruh Perceived Ease of Use, Enjoyment dan Trust Terhadap Repurchase Intention dengan Customer Satisfaction Sebagai Intervening pada Belanja Online (Studi Pada Mahasiswa Universitas Tanjungpura Pontianak)
}

\author{
Juniwati* \\ Universitas Tanjungpura
}

\begin{abstract}
This study aims to determine the influence of perceived ease of use, perceived enjoyment, and trust on customer satisfaction and repurchase intention in online shopping of apparel. The design of the study is a survey research with type of research is explanatory, sample used of 100 people. The data analysis technique used is path analysis. The results showed that perceived ease of use variable has no significant influence on customer satisfaction, while perceived enjoyment and trusts have positive and significant influence on customer satisfaction. The results also showed that perceived enjoyment and customer satisfaction has no significant influence on repurchase intention, while perceived ease of use and trust has positive and significant influence on repurchase intention.
\end{abstract}

Keyword: Perceived Ease of Use, Enjoyment, Trust, Repurchase Intention, Customer Satisfaction

\section{PENDAHULUAN}

Perkembangan teknologi internet yang semakin canggih memberikan manfaat bagi banyak pihak, termasuk para pelaku bisnis di Indonesia. Bisnis online berkembang pesat di tanah air yang ditandai dengan semakin banyaknya pelaku bisnis menggunakan internet sebagai media pemasaran mereka, seperti untuk berpromosi, berinteraksi dan berhubungan dengan pelanggan.

Fakta perkembangan pasar online menunjukkan perubahan perilaku konsumen, dalam berbelanja online sebagai alternatif lain dalam memenuhi kebutuhan sehari-hari. Namun untuk merebut peluang pasar ini tentunya tidak mudah. Kondisi persaingan pasar sangat ketat, tidak hanya secara domestik, regional tetapi persaingan global. Dengan

\footnotetext{
* Korespondensi: Juniwati, Jurusan Manajemen, Fakultas Ekonomi, Universitas Tanjungpura, Jalan Prof. Dr. H. Hadari Nawawi, Pontianak, Indonesia. Alamat Email: juniwati.feuntan@yahoo.co.id
} 
demikian memahami perilaku konsumen dalam konsep e-commerce penting dan jauh lebih rumit dibandingkan dengan memahami konsumen tradisional (Wen, Victor \& Chenyan, 2011).

Faktor kepuasan telah banyak digunakan dalam berbagai penelitian, yang berkaitan dengan faktor-faktor yang mempengaruhi niat pembelian ulang dalam konteks e-commerce (Wen et al., 2011). Menurut Gefen, Karahanna \& Straub (2003) niat penggunaan kembali terutama ditujukan pada individu untuk melakukan pembelian ulang secara online melalui internet. Repurchase intention merupakan tindakan konsumen pasca pembelian. Terjadinya kepuasan dan ketidakpuasan pasca pembelian konsumen terhadap suatu produk akan mempengaruhi perilaku selanjutnya. Jika konsumen puas, maka akan menunjukkan kemungkinan yang lebih tinggi untuk membeli kembali produk tersebut (Kotler \& Keller, 2012).

Niat pembelian ulang belanja online dapat dipengaruhi oleh berbagai faktor diantaranya perceived usefulness, perceived ease of use, perceived enjoyment, perceived security dan privacy concerns (Cha, 2011). Sedangkan menurut Wen et al. (2011), online repurchase intention dapat dipengaruhi oleh perceived ease of use, confirmation, trust, perceived usefulness, satisfaction dan perceived enjoyment. Menurut Lin, Kwoting \& Chien-Chung (2010), niat pembelian ulang belanja online dipengaruhi oleh faktor perceived usefulness, perceived ease of use, concentration, enjoyment dan customer satisfaction.

Berdasarkan uraian di atas, tujuan penelitian ini adalah untuk mengetahui: Pengaruh perceived ease of use, perceived enjoyment, trust terhadap customer satisfaction dan repurchase intention, serta pengaruh customer satisfaction terhadap repurchase intention pada belanja online pakaian jadi.

\section{TINJAUAN PUSTAKA}

\subsection{Repurchase Intention}

Repurchase intention merupakan tindakan konsumen pasca pembelian. Terjadinya kepuasan dan ketidakpuasan pasca pembelian konsumen terhadap suatu produk akan mempengaruhi perilaku selanjutnya. Jika konsumen puas, maka akan menunjukkan kemungkinan yang lebih tinggi untuk membeli kembali produk tersebut (Kotler \& Keller, 2012). Minat membeli merupakan dorongan konsumen untuk melakukan pembelian atau dorongan yang dimiliki oleh seseorang untuk melakukan pembelian ulang. Niat beli yang terdapat pada diri seseorang untuk melakukan suatu perilaku dipengaruhi oleh sikap maupun variabel lainnya. Beberapa indikator yang dapat digunakan untuk variabel ini antara lain adalah berniat melakukan pembelian ulang, merekomendasikan pada orang lain, melakukan word of mouth. 


\subsection{Customer Satisfaction}

Menurut Lovelock \& Wright (2011), kepuasan pelanggan adalah reaksi emosional jangka pendek pelanggan terhadap kinerja jasa tertentu. Tingkat kepuasan merupakan fungsi dari perbedaan antara kinerja layanan yang dirasakan dengan harapan. Bila kinerja layanan di bawah harapan, maka konsumen akan kecewa. Bila kinerja sesuai dengan harapan maka konsumen akan merasa puas. Sedangkan menurut Kotler dan Keller (2012), kepuasan konsumen adalah tingkat perasaan seseorang setelah membandingkan antara kinerja yang dirasakan dengan harapan. Adapun indicator yang dapat digunakan untuk variabel ini antara adalah kepuasan terhadap produk, proses pembelian, servis/pelayanan.

\subsection{Perceived Ease Of Use}

Persepsi kemudahan penggunaan (perceived ease of use) didefenisikan sebagai tingkat kepercayaan individu yang menggunakan teknologi baru akan bebas dari kesulitan (Davis, 1989). Ini mempunyai pengaruh kuat pada niat perilaku pada adopsi teknologi informasi. Jika suatu teknologi dipersepsikan mudah untuk digunakan, orang akan memilih untuk melaksanakan. Penerapan kemudahan penggunaan dalam konteks penelitian adalah bahwa konsumen percaya belanja melalui internet akan flesibel dalam melakukan pembelian, mudah dalam mempelajari penggunaan website, prosedur pembeliannya jelas.

\subsection{Perceived Enjoyment}

Perceived enjoyment dapat dikatakan suatu kondisi dimana kegiatan untuk menggunakan sistem tertentu, dianggap menyenangkan dalam dirinya sendiri, selain dari setiap konsekuensi kinerja yang dihasilkan dari penggunaan sistem. Enjoyment didefenisikan sebagai suatu kesadaran dari sensasi secara holistic, ketika orang secara total terlibat dalam aktivitas tertentu. Kenikmatan belanja online sama pentingnya dengan kenikmatan dalam lingkungan perbelanjaan fisik, dan memiliki pengaruh penting pada niat dan perilaku pelanggan (Koufaris, 2005). Adapun indicator yang digunakan untuk variabel ini, antara lain: belanja online menyenangkan, mengasyikkan dan menarik.

\subsection{Trust}

Trust merupakan pondasi dari bisnis. Suatu transaksi bisnis antara dua pihak atau lebih akan terjadi apabila masing-masing saling mempercayai. Kepercayaan (trust) ini tidak begitu saja dapat diakui oleh pihak lain/mitra bisnis, melainkan harus dibangun mulai dari awal dan dapat dibuktikan. Trust telah dipertimbangkan sebagai katalis dalam berbagai transaksi antara penjual dan pembeli agar kepuasan konsumen dapat terwujud sesuai dengan yang diharapkan (Yousafzai, Pallister \& Foxall, 2003). Adapun indikator 
yang digunakan untuk variabel ini antara lain; belanja online aman, dapat dipercaya, jujur, pelayanannya baik.

\subsection{Hipotesis}

H1 : Perceived ease of use berpengaruh signifikan terhadap customer satisfaction pada belanja online pakaian.

H2 : Perceived enjoyment berpengaruh signifikan terhadap customer satisfaction pada belanja online pakaian.

H3 : Trust berpengaruh signifikan terhadap customer satisfaction pada belanja online pakaian.

$\mathrm{H} 4$ : Perceived ease of use berpengaruh signifikan terhadap repurchase intention online pakaian.

H5 : Perceived enjoyment berpengaruh signifikan terhadap repurchase intention online pakaian.

H6 : Trust berpengaruh signifikan terhadap repurchase intention online pakaian

$\mathrm{H} 7$ : Customer satisfaction berpengaruh signifikan terhadap repurchase intention online pakaian.

\section{METODE PENELITIAN}

Penelitian ini merupakan penelitian survei dengan bentuk penelitian eksplanatori. Target populasi adalah mahasiswa Universitas Tanjungpura yang pernah melakukan belanja online minimal 2 kali, peneliti menetapkan jumlah sampel dalam penelitian ini sebanyak 100 responden yang diambil secara proporsional dari masing-masing fakultas, teknik penarikan sampelnya dilakukan secara purposive. Untuk skala data dalam penelitian ini diukur dengan menggunakan skala likert yang diklasifikasikan sebagai data interval. Dalam hal ini dibuat urutan sebagai berikut : sangat setuju diberi nilai 5 , setuju diberi nilai 4, netral diberi nilai 3, tidak setuju diberi nilai 2, dan sangat tidak setuju diberi nilai 1. Untuk menganalisis data dalam penelitian ini digunakan teknis analisis jalur (path analysis) dengan menggunakan paket SPSS.

\section{TEMUAN DAN PEMBAHASAN}

\subsection{Deskripsi Karakteristik Responden}

Berdasarkan data yang diperoleh dari kuesioner, dapat digambarkan bahwa posisi semester responden terbanyak berada pada semester 5 yaitu sebanyak $53 \%$, yang kedua berada di semester tiga sebanyak 36\%. Adapun gender dari responden lebih banyak berjenis kelamin perempuan $(80 \%)$. Jika dilihat dari lamanya waktu yang digunakan responden dalam sehari untuk menggunakan internet, maka dari 100 responden paling 
banyak menggunakan internet per hari lebih dari 4 jam sebanyak 29 orang (29\%) dan sebanyak 26\% menggunakan internet per hari antara 2-3 jam.

Berdasarkan lamanya penggunaan internet dalam sehari, maka responden pada penelitian ini dapat digolongkan pengguna internet sedang dan berat. Berdasarkan kegiatan yang dilakukan melalui internet, maka yang paling dominan adalah untuk kegiatan bermain yaitu sebanyak 39\%. Kegiatan lainnya yang dilakukan melalui internet adalah jejaring atau media sosial yaitu sebanyak 35\%, dan selebihnya menggunakan internet untuk browsing yaitu sebanyak 26\%. Kegiatan browsing dilakukan antara lain untuk mencari materi perkuliahan, jurnal penelitian, dan mengerjakan tugas-tugas perkuliahan. Dengan demikian dapat diartikan sebagian besar responden menggunakan internet untuk hal-hal yang tidak produktif.

Cara melakukan pembayaran untuk belanja online paling banyak menggunakan transfer via ATM (66\%). Produk yang paling banyak dibeli secara online adalah pakaian sebanyak $(75 \%)$. Berdasarkan media yang digunakan untuk belanja online, maka media yang terbanyak digunakan adalah melalui facebook (45\%) dan smartphone (30\%). Berdasarkan ketertarikan pada iklan di internet (71\%) menyatakan tertarik. Selalu membeli pada penjual yang sama $(33 \%)$ dan $(67 \%)$ tidak selalu membeli pada penjual yang sama, dari sampel ini menggambarkan pelanggan online bukanlah pelanggan yang loyal. Berdasarkan faktor yang dipertimbangkan dari penjual online, maka faktor kemudahan penggunaan (42\%) dan kepercayaan (35\%).

\subsection{Deskripsi Variabel Penelitian}

Penentuan kategori rata-rata variabel penelitian didasarkan atas perhitungan kategori nilai rata-rata dengan rentang skor $=0,8$, maka kategori nilai rata-rata variabel adalah: 1 hingga 1,7 = sangat rendah; 1,8 hingga 2,5 = rendah; 2,6 hingga 3,3 = sedang; 3,4 hingga 4,1 = tinggi; 4,2 hingga 5 = sangat tinggi.

Tabel 1. Analisis Data Deskriptif Variabel Penelitian

\begin{tabular}{lcc}
\hline \multicolumn{1}{c}{ Variabel } & Rata-rata & $\begin{array}{c}\text { Kategori nilai } \\
\text { rata-rata }\end{array}$ \\
\hline Perceived Ease of Use (X1) & \\
- Mudah membandingkan pakaian yang akan dibeli. & 3,58 \\
- Mudah menemukan pakaian yang diinginkan. & 3,93 \\
- Panduan pembelian pakaian melalui online jelas dan mudah dipahami. & 3,75 \\
- Secara keseluruhan, saya berpendapat bahwa pembelian pakaian & 3,90 \\
melalui online mudah untuk dilakukan. & \\
\hline Mean Variabel & $\mathbf{3 , 7 9}$ & Tinggi \\
\hline
\end{tabular}


Tabel 1. (Lanjutan)

\section{Perceived Enjoyment (X2)}

- Mengunjungi website toko pakaian online merupakan suatu kegiatan 4,05 yang menarik.

- Proses mencari pakaian yang saya inginkan melalui internet sangat 4,03 menyenangkan.

- Berinteraksi dengan penjual maupun dengan sesama pembeli saat 3,41 berbelanja pakaian secara online sangat menghibur.

- Secara keseluruhan, saya sangat menikmati pengalaman berbelanja 3,67 pakaian secara online.

Mean Indikator 3,79

Tinggi

Trust (X3)

- Saya merasa situs penjualan pakaian secara online akan memberikan pelayanan yang baik.

- Saya percaya dengan situs penjualan pakaian secara online dapat menjaga kerahasiaan data pribadi saya.

- Saya percaya, pakaian yang akan dikirim sesuai dengan pesanan (kualitas, warna dan ukuran)

- Saya percaya barang akan dikirim tepat waktu atau sesuai janji.

3,18

\begin{tabular}{lcc}
\hline \multicolumn{1}{c}{ Mean Variabel } & $\mathbf{3 , 3 5}$ & Sedang \\
\hline \multicolumn{1}{c}{ Customer Satisfaction (Y1) } & \\
- Saya puas dengan keragaman pakaian yang ditawarkan secara online. & 3,91 \\
- Jangka waktu pengiriman pakaian yang dibeli secara online sesuai & 3,32 \\
dengan harapan saya. & 3,50 \\
- Saya puas dengan kesigapan penjual pakaian online dalam melayani \\
$\begin{array}{l}\text { pembeli. } \\
\text { - Secara keseluruhan, saya merasa puas dengan sistem berbelanja } \\
\text { pakaian secara } \text { online. }\end{array}$ \\
\hline Mean Indikator & 3,69 \\
\hline
\end{tabular}

\section{Repurchase Intention (Y2)}

- Saya lebih memilih berbelanja pakaian secara online dibandingkan offline.

- Dalam waktu dekat maupun jangka panjang saya akan terus membeli pakaian secara online.

- Saya akan merekomendasikan pembelian secara online kepada orang lain.

- Saya akan bercerita kepada orang lain tentang pengalaman positif saat belanja pakaian secara online. 


\subsection{Hasil Analisis Dan Uji Hipotesis Pengaruh Perceived Ease Of Use (X1), Perceived Enjoyment (X2) Dan Trust (X3), Terhadap Customer Satisfaction (Y1) dan Repurchase Intention (Y2)}

Berdasarkan Tabel 2 terlihat bahwa nilai R sebesar 0,487 menunjukkan bahwa hubungan antara keseluruhan variabel yang diteliti yaitu X1, X2, X3 terhadap Y1 adalah sebesar $48,7 \%$. Besarnya angka ini menunjukkan hubungan yang diinter-prestasikan sebagai hubungan yang sedang.

Tabel 2. Hasil Koefisien Determinasi

\begin{tabular}{|c|c|c|c|c|}
\hline \multicolumn{5}{|c|}{ Model Summary $^{b}$} \\
\hline Model & $\mathrm{R}$ & R Square & $\begin{array}{l}\text { Adjusted R } \\
\text { Square }\end{array}$ & $\begin{array}{c}\text { Std. Error of the } \\
\text { Estimate }\end{array}$ \\
\hline 1 & $.698^{\mathrm{a}}$ & 0.487 & 0.471 & 1.524 \\
\hline
\end{tabular}

Nilai Adjusted $\mathrm{R}^{2}$ sebesar 0,471 menunjukkan bahwa besarnya pengaruh secara simultan X1, X2, X3 terhadap Y1 sebesar 47,1\%, besarnya angka ini menunjukkan hubungan yang di interpretasikan sebagai hubungan yang tinggi dan sisanya sebesar $52,9 \%$ dapat dijelaskan oleh faktor-faktor lain yang tidak diteliti dalam penelitian ini.

Berdasarkan Tabel 3 terlihat bahwa nilai $\mathrm{R}$ sebesar 0,404 menunjukkan bahwa hubungan antara keseluruhan variabel yang diteliti yaitu X1, X2, X3 dan Y1 terhadap Y2 adalah sebesar 40,4\%. Besarnya angka ini menunjukkan hubungan yang diinterprestasikan sebagai hubungan yang sedang.

\section{Tabel 3. Hasil Koefisien Determinasi}

\begin{tabular}{|c|c|c|c|c|}
\hline \multicolumn{5}{|c|}{ Model Summary $^{b}$} \\
\hline Model & $\mathrm{R}$ & R Square & $\begin{array}{c}\text { Adjusted R } \\
\text { Square }\end{array}$ & $\begin{array}{l}\text { Std. Error of the } \\
\text { Estimate }\end{array}$ \\
\hline 1 & $.635^{\mathrm{a}}$ & 0.404 & 0.379 & 1.685 \\
\hline
\end{tabular}

Nilai Adjusted $\mathrm{R}^{2}$ sebesar 0,379 menunjukkan bahwa besarnya pengaruh secara simultan X1, X2, X3 dan Y1 terhadap Y2 sebesar 37,9\%, besarnya angka ini menunjukkan hubungan yang di interpretasikan sebagai hubungan yang tinggi dan sisanya sebesar $62,1 \%$ dapat dijelaskan oleh faktor-faktor lain yang tidak diteliti dalam penelitian ini. 
4.3.1. Pengujian Hipotesis Pengaruh Perceived Ease Of Use (X1), Perceived Enjoyment (X2) Dan Trust (X3), Terhadap Customer Satisfaction (Y1)

Hasil analisis regresi pada Tabel 4 menjelaskan bahwa secara bersama-sama variabel independen yang diteliti yaitu X1, X2 dan X3 memiliki pengaruh yang signifikan terhadap variabel dependen yaitu (Y1). Hal ini dapat dibuktikan dari nilai $\mathrm{F}$ hitung sebesar 30,377 dengan nilai signifikansi sebesar 0,000. Karena probabilitas jauh lebih kecil dari 0,05 atau 5\%, maka model regresi dapat digunakan untuk memprediksi (Y1) atau dapat dikatakan bahwa (X1), (X2) dan (X3) secara bersama-sama berpengaruh terhadap (Y1).

Tabel 4. Hasil Uji F (simultan)

\begin{tabular}{|c|c|c|c|c|c|c|}
\hline \multicolumn{7}{|c|}{ ANOVA $^{\mathbf{b}}$} \\
\hline Model & & Sum of Squares & $\mathrm{df}$ & Mean Square & $\mathrm{F}$ & Sig. \\
\hline \multirow[t]{3}{*}{1} & Regression & 211.529 & 3 & 70.510 & 30.377 & $.000^{\mathrm{a}}$ \\
\hline & Residual & 222.831 & 96 & 2.321 & & \\
\hline & Total & 434.360 & 99 & & & \\
\hline
\end{tabular}

a. Predictors: (Constant), X3, X2, X1

b. Dependent Variable: Y1

Hasil analisis regresi pada Tabel 5 menjelaskan bahwa secara bersama-sama variabel independen yang diteliti yaitu $(X 1),(X 2),(X 3)$ dan $(Y 1)$ memiliki pengaruh yang signifikan terhadap variabel dependen yaitu $(Y 2)$. Hal ini dapat dibuktikan dari nilai $\mathrm{F}$ hitung sebesar 16,085 dengan nilai signifikansi sebesar 0,000. Karena probabilitas jauh lebih kecil dari 0,05 atau 5\%, maka model regresi dapat digunakan untuk memprediksi (Y2) atau dapat dikatakan bahwa $(X 1),(X 2),(X 3)$ dan (Y1) secara bersama-sama berpengaruh terhadap $(Y 2)$.

Tabel 5. Hasil Uji F (simultan)

\begin{tabular}{|c|c|c|c|c|c|c|}
\hline \multicolumn{7}{|c|}{ ANOVA $^{b}$} \\
\hline Model & & Sum of Squares & df & Mean Square & $\mathrm{F}$ & Sig. \\
\hline 1 & Regression & 182.753 & 4 & 45.688 & 16.085 & $.000^{\mathrm{a}}$ \\
\hline & Residual & 269.837 & 95 & 2.84 & & \\
\hline & Total & 452.59 & 99 & & & \\
\hline
\end{tabular}

a. Predictors: (Constant), Y1, X1, X3, X2

b. Dependent Variable: Y2

Berdasarkan pengolahan data dengan menggunakan program SPSS versi 17, diketahui besarnya pengaruh parsial variabel independen terhadap variabel dependen. Hasil Uji t (parsial) ditunjukkan ditunjukkan pada Tabel 6 sebagai berikut. 
Tabel 6. Uji t (parsial)

\begin{tabular}{|c|c|c|c|c|c|c|}
\hline & \multicolumn{6}{|c|}{ Coefficients $^{\mathrm{a}}$} \\
\hline & \multirow[b]{2}{*}{ Model } & \multicolumn{2}{|c|}{ Unstandardized Coefficients } & Standardized Coefficients & \multirow[b]{2}{*}{$\mathrm{t}$} & \multirow[b]{2}{*}{ Sig. } \\
\hline & & B & Std. Error & Beta & & \\
\hline \multirow[t]{4}{*}{1} & (Constant) & 2.417 & 1.307 & & 1.85 & 0.067 \\
\hline & $\mathrm{X} 1$ & 0.128 & 0.099 & 0.126 & 1.295 & 0.198 \\
\hline & $\mathrm{X} 2$ & 0.305 & 0.086 & 0.336 & 3.526 & 0.001 \\
\hline & $\mathrm{X} 3$ & 0.406 & 0.082 & 0.404 & 4.982 & 0 \\
\hline
\end{tabular}

a. Dependent Variable: Y1

Berdasarkan Tabel 6 dapat terlihat bahwa koefisien regresi untuk variabel X1 sebesar 0,126 dan $\mathrm{t}$ hitung 1,295 dengan tingkat signifikan sebesar 0,198, dimana nilai signifikan ini lebih tinggi dari 0,05. Hal ini menunjukkan bahwa secara parsial variabel X1 tidak berpengaruh positif dan signifikan terhadap Y1, yang ditunjukkan dari nilai signifikansi sebesar 0,198>0,05. Dengan demikian $\mathrm{H} 1$ : perceived ease of use berpengaruh terhadap customer satisfaction pada belanja online ditolak.

Koefisien regresi untuk variabel X2 sebesar 0,336 dan $\mathrm{t}_{\text {hitung }}$ 3,526 dengan tingkat signifikan sebesar 0,001 dimana nilai signifikan ini lebih rendah dari 0,05. Hal ini menunjukkan bahwa secara parsial variabel X2 berpengaruh positif dan signifikan terhadap Y1, yang ditunjukkan dari nilai signifikansi sebesar 0,001 $<0,05$. Dengan demikian $\mathrm{H} 2$ : perceived enjoyment berpengaruh terhadap customer satisfaction pada belanja online diterima.

Koefisien regresi untuk variabel X3 sebesar 0,404 dan $\mathrm{t}_{\text {hitung }}$ 4,982 dengan tingkat signifikan sebesar 0,000 dimana nilai signifikan ini lebih rendah dari 0,05. Hal ini menunjukkan bahwa secara parsial variabel X3 berpengaruh positif dan signifikan terhadap Y1, yang ditunjukkan dari nilai signifikansi sebesar $0,000<0,05$. Dengan demikian H3: trust berpengaruh terhadap customer satisfaction pada belanja online diterima.

4.3.2. Pengujian Hipotesis Pengaruh Perceived Ease Of Use (X1), Perceived Enjoyment (X2), Trust (X3) Dan Customer Satisfaction (Y1) Terhadap Repurchase Intention $(Y 2)$

Uji t (parsial) Variabel Independen yaitu X1, X2, X3 dan Y1 ditunjukkan pada Tabel 7 sebagai berikut. Berdasarkan Tabel 7, dapat terlihat bahwa diperoleh koefisien regresi untuk variabel $\mathrm{X} 1$ sebesar 0,309 dan $\mathrm{t}$ hitung 2,900 dengan tingkat signifikan sebesar 0,005, dimana nilai signifikan ini lebih kecil dari 0,05. Hal ini menunjukkan bahwa secara parsial variabel X1 berpengaruh positif dan signifikan terhadap Y2, yang ditunjukkan dari nilai signifikansi sebesar 0,005 < 0,05. Dengan demikian H4: perceived ease of use berpengaruh terhadap repurchase intention online diterima. 


\section{Tabel 7. Uji t (parsial)}

\begin{tabular}{|c|c|c|c|c|c|c|}
\hline & \multicolumn{6}{|c|}{ Coefficients $^{\mathrm{a}}$} \\
\hline & \multirow[b]{2}{*}{ Model } & \multicolumn{2}{|c|}{ Unstandardized Coefficients } & Standardized Coefficients & \multirow[b]{2}{*}{$\mathrm{t}$} & \multirow{3}{*}{$\begin{array}{c}\text { Sig. } \\
0.279\end{array}$} \\
\hline & & B & Std. Error & Beta & & \\
\hline \multirow[t]{5}{*}{1} & (Constant) & 1.6 & 1.471 & & 1.088 & \\
\hline & $\mathrm{X} 1$ & 0.32 & 0.111 & 0.309 & 2.9 & 0.005 \\
\hline & $\mathrm{X} 2$ & 0.131 & 0.102 & 0.142 & 1.293 & 0.199 \\
\hline & $\mathrm{X} 3$ & 0.251 & 0.101 & 0.244 & 2.479 & 0.015 \\
\hline & Y1 & 0.103 & 0.113 & 0.101 & 0.91 & 0.365 \\
\hline
\end{tabular}

a. Dependent Variable: Y2

Koefisien regresi untuk variabel X2 sebesar 0,142 dan $\mathrm{t}$ hitung 1,293 dengan tingkat signifikan sebesar 0,199, dimana nilai signifikan ini lebih tinggi dari 0,05. Hal ini menunjukkan bahwa secara parsial variabel X2 tidak berpengaruh positif dan signifikan terhadap Y2, yang ditunjukkan dari nilai signifikansi sebesar 0,199>0,05. Dengan demikian H5: perceived enjoyment berpengaruh terhadap repurchase intention online ditolak.

Koefisien regresi untuk variabel X3 sebesar 0,244 dan $\mathrm{t}_{\text {hitung }}$ 2,479 dengan tingkat signifikan sebesar 0,015 dimana nilai signifikan ini lebih kecil dari 0,050. Hal ini menunjukkan bahwa secara parsial variabel X3 berpengaruh positif dan signifikan terhadap Y2, yang ditunjukkan dari nilai signifikansi sebesar $0,015<0,05$. Dengan demikian H6: trust berpengaruh terhadap repurchase intention online diterima.

Koefisien regresi untuk variabel Y1 sebesar 0,101 dan $\mathrm{t}_{\text {hitung }} 0,910$ dengan tingkat signifikan sebesar 0,365 dimana nilai signifikan ini lebih tinggi dari 0,05. Hal ini menunjukkan bahwa secara parsial variabel Y1 tidak berpengaruh positif dan signifikan terhadap Y2, yang ditunjukkan dari nilai signifikansi sebesar 0,365 $>0,05$. Dengan demikian H7: customer satisfaction berpengaruh terhadap repurchase intention online ditolak.

\subsection{Analisis Jalur (Path Analysis)}

Untuk mengetahui pola hubungan X1, X2, X3, Y1 dan Y2, akan diuji melalui beberapa hipotesis. Hipotesis-hipotesis tersebut dianalisis dengan menggunakan analisis jalur (path analysis).

\subsubsection{Analisis Jalur Sub Struktur I}

Dalam model pertama ini akan diteliti pola hubungan antara variabel X1, X2, X3 terhadap Y1 dengan menggunakan analisis regresi berganda. Persamaan struktural dalam model pertama ini adalah:

$$
\mathrm{Y}_{1}=\mathrm{p} \mathrm{Y}_{1} \mathrm{X}_{1}+\mathrm{p} \mathrm{Y}_{1} \mathrm{X}_{2}+\mathrm{p} \mathrm{Y}_{1} \mathrm{X}_{3}+\mathrm{e}_{1}
$$


Dengan perhitungan analisis jalur adalah sebagai berikut:

Tabel 8. Hasil Analisis Jalur Variabel $X 1, X 2, X 3$ Terhadap $Y 1$

\begin{tabular}{|c|c|c|c|}
\hline Variabel & Standardized Coefficient Beta & $\mathbf{t}$ & Sig. \\
\hline Perceived Ease of Use $\left(\mathrm{X}_{1}\right)$ & 0,126 & 1,295 & 0,198 \\
\hline Perceived Enjoyment $\left(\mathrm{X}_{2}\right)$ & 0,336 & 3,526 & 0,001 \\
\hline Trust $\left(\mathrm{X}_{3}\right)$ & 0,404 & 4,982 & 0,000 \\
\hline
\end{tabular}

Sementara untuk menghitung nilai error pada persamaan sub struktur I dapat dilakukan dengan rumus sebagai berikut:

$$
\begin{aligned}
& \mathrm{Pe}_{1}=\sqrt{1-\mathrm{Ri}} \\
& \mathrm{Pe}_{1}=\sqrt{1-0,487}=0,716
\end{aligned}
$$

\subsubsection{Analisis Jalur Sub Struktur II}

Dalam model pertama ini akan diteliti pola hubungan antara variabel X1, X2, X3 dan Y1 terhadap Y2 dengan persamaan struktural sebagai berikut :

$Y_{2}=p Y_{2} X_{1}+p Y_{2} X_{2}+p Y_{2} X_{3}+p Y_{2} Y_{1}+e_{1}$

Dengan perhitungan analisis jalur adalah sebagai berikut :

Tabel 9. Hasil Analisis Jalur Variabel X1, X2, X3 dan Y1 Terhadap Y2

\begin{tabular}{lccc}
\hline \multicolumn{1}{c}{ Variabel } & Standardized Coefficient Beta & t & Sig. \\
\hline Perceived Ease of Use (X1) & 0,309 & 2,900 & 0,005 \\
Perceived Enjoyment (X2) & 0,142 & 1,293 & 0,199 \\
Trust (X3) & 0,244 & 2,479 & 0,015 \\
Customer Satisfaction (Y1) & 0,101 & 0,910 & 0,365 \\
\hline \multicolumn{1}{c}{ R Square = 0,404 } & & &
\end{tabular}

Untuk menghitung nilai error pada persamaan sub struktur II dapat dilakukan dengan rumus sebagai berikut:

$$
\begin{aligned}
& \mathrm{Pe}_{2}=\sqrt{1-\mathrm{Ri}} \\
& \mathrm{Pe}_{2}=\sqrt{1-0,404}=0,772
\end{aligned}
$$

Berdasarkan hasil dari perhitungan koefisien jalur pada sub struktur I dan sub mempunyai persamaan struktur menjadi sebagai berikut :

$Y_{1}=0,126 X_{1}+0,336 X_{2}+0,404 X_{3}+0,716$

$\mathrm{Y}_{2}=0,309 \mathrm{X}_{1}+0,142 \mathrm{X}_{2}+0,244 \mathrm{X}_{3}+0,101 \mathrm{Y}_{1}+0,772$ 
Rekapitulasi pengaruh langsung, pengaruh tidak langsung dan pengaruh total dari hasil penelitian dapat diuraikan pada Tabel 10. Untuk menilai kebaikan model riset (goodness of fit) dapat diketahui melalui perhitungan koefisien determinasi total sebagai berikut :

$$
\begin{aligned}
\mathrm{R}^{2} \mathrm{~m} & =1-\left(\mathrm{Pe}_{1}\right)^{2} \cdot\left(\mathrm{Pe}_{2}\right)^{2} \\
& =1-(0,716)^{2} \cdot(0,772)^{2} \\
& =0,694 \approx 69,4 \%
\end{aligned}
$$

Nilai koefisien determinasi total sebesar 69,4\% menunjukkan bahwa 69,4\% informasi yang terkandung dalam data dapat dijelaskan oleh model, sedangkan sisanya sebesar 30,6\% dijelaskan oleh error dan variabel lain di luar model. Angka koefisien 69,4\% dapat dikatakan cukup tinggi karena $>50 \%$ sehingga layak untuk dilakukan interpretasi lebih lanjut.

Tabel 10. Pengaruh Langsung, Tidak Langsung dan Total dari Jalur Penelitian

\begin{tabular}{lccc}
\hline \multicolumn{1}{c}{ Keterangan } & Pengaruh Langsung & Pengaruh Tidak Langsung & Pengaruh Total \\
\hline $\mathrm{X} 1 \rightarrow \mathrm{Y} 1$ & 0,126 & - & - \\
$\mathrm{X} 2 \rightarrow \mathrm{Y} 1$ & 0,336 & - & - \\
$\mathrm{X} 3 \rightarrow \mathrm{Y} 1$ & 0,404 & - & - \\
$\mathrm{X} 1 \rightarrow \mathrm{Y} 2$ & 0,309 & - & - \\
$\mathrm{X} 2 \rightarrow \mathrm{Y} 2$ & 0,142 & - & - \\
$\mathrm{X} 3 \rightarrow \mathrm{Y} 2$ & 0,244 & - & - \\
$\mathrm{Y} 1 \rightarrow \mathrm{Y} 2$ & 0,101 & 0,013 & - \\
$\mathrm{X} 1 \rightarrow \mathrm{Y} 1 \rightarrow \mathrm{Y} 2$ & - & $0,126 \times 0,101)$ & 0,322 \\
& & 0,034 & $0,309+0,013)$ \\
$\mathrm{X} 2 \rightarrow \mathrm{Y} 1 \rightarrow \mathrm{Y} 2$ & - & $0,336 \times 0,101)$ & 0,176 \\
& & 0,041 & $0,142+0,034)$ \\
$\mathrm{X} 3 \rightarrow \mathrm{Y} 1 \rightarrow \mathrm{Y} 2$ & & $(0,404 \times 0,101)$ & 0,285 \\
& & & $(0,244+0,041)$ \\
\hline
\end{tabular}

\subsection{Teori Trimming}

Langkah selanjutnya setelah analisis jalur (path analysis) adalah melakukan teori trimming, dimana apabila terdapat koefisien jalur dari variabel eksogen yang tidak memiliki pengaruh signifikan terhadap variabel endogen maka koefisien jalur dari variabel eksogen yang tidak signifikan tersebut dihilangkan dari diagram jalur dan dibuat diagram baru.

Dalam penelitian ini karena variabel $\mathrm{X} 1$ terbukti tidak berpengaruh signifikan terhadap Y1, variabel X2 terbukti tidak berpengaruh signifikan terhadap Y2, dan variabel Y1 terbukti tidak berpengaruh signifikan terhadap Y2 maka variabel tersebut dihilangkan dari diagram jalur sehingga dibuat diagram baru menjadi sebagai berikut. 


\subsubsection{Sub Struktur I}

Pada sub struktur I yang baru ini dilakukan analisis regresi variabel X2 dan X3 dengan Y1 dengan hasil sebagai berikut:

Tabel 11. Hasil Analisis Regresi Teori Trimming Variabel $X 2$ dan $X 3$ Terhadap $Y 1$

\begin{tabular}{lccc}
\hline \multicolumn{1}{c}{ Variabel } & Standardized Coefficient Beta & T & Sig. \\
\hline Perceived Enjoyment $\left(\mathrm{X}_{2}\right)$ & 0,406 & 5,153 & 0,000 \\
Trust $\left(\mathrm{X}_{3}\right)$ & 0,430 & 5,459 & 0,000 \\
\hline \multicolumn{1}{c}{ R Square $=0,478$} & & & \\
\hline
\end{tabular}

Untuk menghitung nilai error pada persamaan sub struktut I dapat dilakukan dengan rumus sebagai berikut :

$$
\begin{aligned}
& \overline{\mathrm{Pe}_{1}=\sqrt{1}}-\mathrm{Ri} \\
& \overline{\mathrm{Pe}_{1}=\sqrt{ } 1}-0,478=0,722
\end{aligned}
$$

\subsubsection{Sub Struktur II}

Pada sub struktur II yang baru ini dilakukan analisis regresi variabel X1 dan X3 terhadap Y2 dengan hasil sebagai berikut.

Tabel 12. Hasil Analisis Regresi Teori Trimming Variabel X1 dan X3 Terhadap Y2

\begin{tabular}{lccc}
\hline \multicolumn{1}{c}{ Variabel } & Standardized Coefficient Beta & t & Sig. \\
\hline Perceived Ease of Use (X1) & 0,423 & 4,824 & 0,000 \\
Trust (X3) & 0,308 & 3,509 & 0,001 \\
\hline \multicolumn{1}{c}{ R Square $=0,380$} & & &
\end{tabular}

Untuk menghitung nilai error pada persamaan sub struktur II dapat dilakukan dengan rumus sebagai berikut:

$$
\begin{aligned}
& \mathrm{Pe}_{2}=\sqrt{1}-\mathrm{Ri} \\
& \overline{\mathrm{Pe}_{2}=\sqrt{ } 1}-0,380=0,787
\end{aligned}
$$

Hasil perhitungan koefisien jalur pada sub struktur I dan sub struktur II yang baru dapat digambarkan secara keseluruhan hubungan kausal empiris antara variabel X1, X1 dan X3 terhadap Y2 melalui Y1 dapat dilihat pada Gambar 1.

Sehingga kebaikan model riset (goodness of fit) yang baru dapat diketahui melalui perhitungan koefisien determinasi total sebagai berikut:

$$
\begin{aligned}
\mathrm{R}^{2} \mathrm{~m} & =1-\left(\mathrm{Pe}_{1}\right)^{2} \cdot\left(\mathrm{Pe}_{2}\right)^{2} \\
& =1-(0,722)^{2} \cdot(0,787)^{2} \\
& =0,677 \approx 67,7 \%
\end{aligned}
$$


Nilai koefisien determinasi total sebesar $67,7 \%$ menunjukkan bahwa $67,7 \%$ informasi yang terkandung dalam data dapat dijelaskan oleh model, sedangkan sisanya sebesar 32,3\% dijelaskan oleh error dan variabel lain diluar model. Angka koefisien $67,7 \% \%$ dapat dikatakan cukup tinggi karena $>50 \%$ sehingga layak untuk dilakukan interpretasi lebih lanjut.

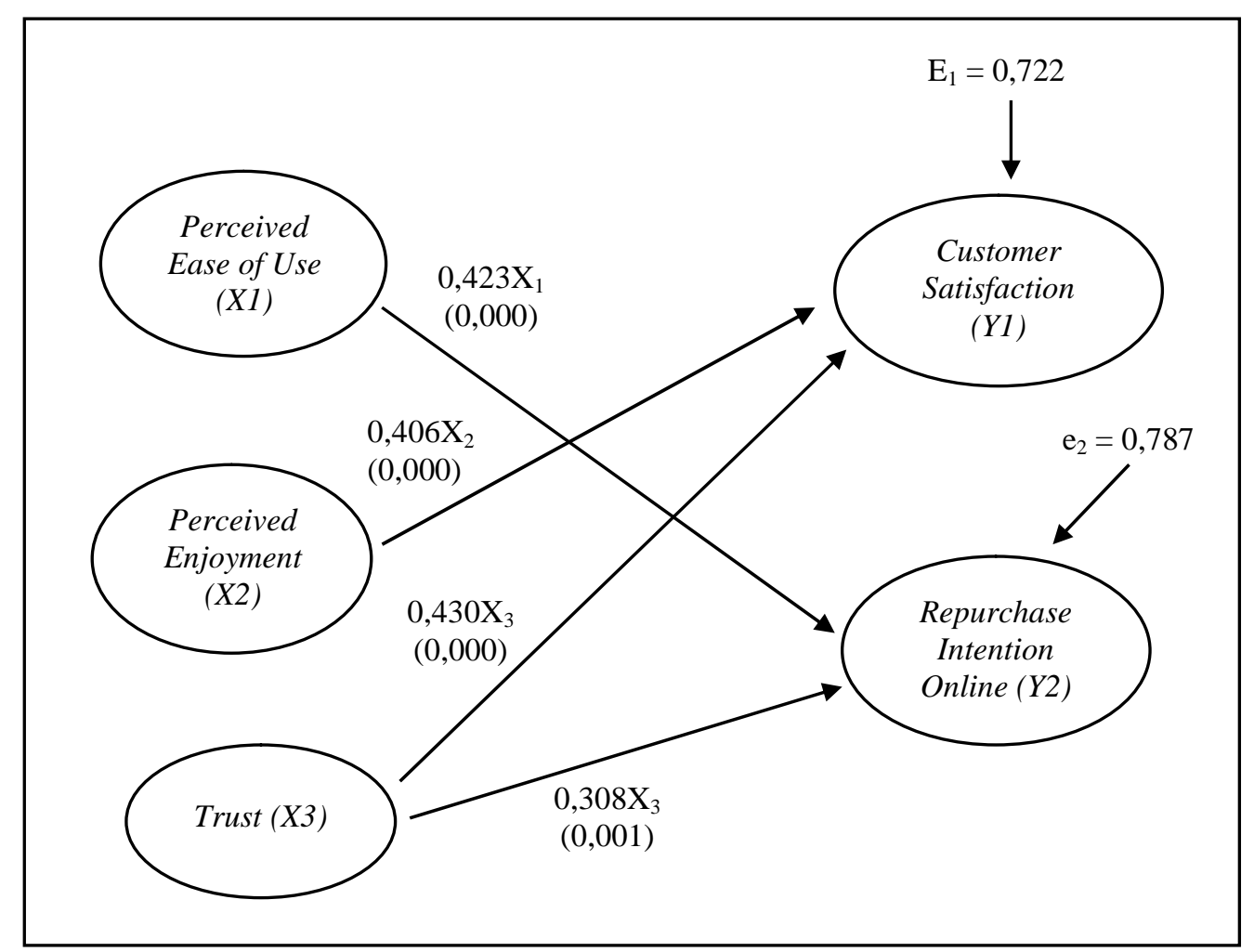

Gambar 1. Diagram Jalur Teori Trimming

Rekapitulasi pengaruh langsung, pengaruh tidak langsung dan pengaruh total dari diagram jalur teori trimming dapat diuraikan sebagai berikut:

Tabel 13. Pengaruh Langsung, Tidak Langsung dan Total Hasil Teori Trimming

\begin{tabular}{lccc}
\hline Keterangan & $\begin{array}{c}\text { Pengaruh } \\
\text { Langsung }\end{array}$ & $\begin{array}{c}\text { Pengaruh Tidak } \\
\text { Langsung }\end{array}$ & Pengaruh Total \\
\hline $\mathrm{X} 2 \rightarrow \mathrm{Y} 1$ & 0,406 & - & - \\
$\mathrm{X} 3 \rightarrow \mathrm{Y} 1$ & 0,430 & - & - \\
$\mathrm{X} 1 \rightarrow$ Y2 & 0,423 & - & - \\
$\mathrm{X} 3 \rightarrow \mathrm{Y} 2$ & 0,308 & - & - \\
\hline
\end{tabular}

Berdasarkan Tabel 13 diatas, kontribusi X2 yang secara langsung mempengaruhi $\mathrm{Y} 1$ adalah $(0,406)^{2}=0,165$ atau sebesar $16,5 \%$. Kontribusi X3 yang secara langsung 
mempengaruhi $\mathrm{Y} 1$ adalah $(0,430)^{2}=0,185$ atau sebesar $18,5 \%$. Kontribusi X1 yang secara langsung mempengaruhi Y2 adalah $(0,423)^{2}=0,179$ atau sebesar $17,9 \%$. Kontribusi X3 yang secara langsung mempengaruhi Y2 adalah $(0,308)^{2}=0,095$ atau sebesar $9,5 \%$.

\section{KESIMPULAN}

Variabel perceived enjoyment dan trust berpengaruh positif dan signifikan terhadap customer satisfaction. Variabel perceived ease of use dan trust berpengaruh positif dan signifikan terhadap repurchase intention. Dengan demikian dari 7 hipotesis yang ada maka 4 hipotesis dapat diterima, dan 3 yang di tolak yaitu hipotesis H1, H5 dan H7. Hasil uji statistik yang dilakukan maka variable trust merupakan variabel yang berpengaruh terhadap kepuasan konsumen dalam berbelanja online dan mempengaruhi mereka untuk melakukan pembelian ulang dengan online. Dengan demikian dapat dikatakan bahwa kepercayaan konsumen pada penjual online yang meliputi; percaya penjual akan memberikan pelayanan yang baik, percaya penjual akan mengirim barang sesuai janji, percaya penjual menjaga data pribadi konsumen, menjadi variabel yang berpengaruh terhadap kepuasan dan niat pembelian ulang konsumen untuk belanja online.

Sementara kemudahan penggunaan bukanlah hal yang dapat memuaskan mereka, namun dipertimbangkan dalam pembelian ulang. Sedangkan enjoyment tidak mempengaruhi konsumen dalam pembelian ulang. Kepuasan akan belanja online tidak mempengaruhi konsumen dalam melakukan pembelian ulang, hal ini disebabkan kemudahan penggunaan dan trust yang lebih diutamakan dan pembeli online disini bukan pelanggan yang setia, seperti yang tergambar dari karakteristik konsumen dimana lebih dari $60 \%$ menyatakan mereka tidak selalu membeli pada penjual yang sama.

Berdasarkan hasil penelitian dapat disarankan (1) bagi penjual online untuk lebih memudahkan penggunaan proses dalam berbelanja secara online, dengan prosedur yang semakin sederhana maka konsumen akan semakin tertarik, (2) membuat dan menjaga kepercayaan konsumen dengan menyebar kebaikan dalam pelayanan dan menjual dalam kelompok-kelompok konsumen yang saling percaya diantara anggotanya kuat, dalam arti rekomendasi antar anggota sangat dipertimbangkan.

\section{DAFTAR PUSTAKA}

Ba, S. \& Pavlou, P. A. (2002). Evidence of the effect of trust building technology in electronic markets: price premiums and buyer behaviour. MIS Quarterly. 26(3), 243-268. 
Boone, L. E., \& Kurtz, D. L. (2005). Contemporary Marketing. Ohio USA. Thomson South Western.

Cha, J. (2011). Exploring the Internet as A Unique Shopping Channel to Sell Both Real and Virtual Items: A Comparison of Factors Affecting Purchase Intention and Consumer Characteristics. Journal of Electronic Commerce Research. 12(2), 115-132.

Chau, P. Y. K.. (1996). An Empirical Assessment of a Modified Technology Acceptance Model. Journal of Management Information Systems. 13(2), 185-204.

Cooper, D. R. \& Schindler, P. S. (2006). Marketing Research. Boston: McGraw-Hill.

Davis, F. D. (1989). Perceived Usefulness, Perceived Ease of Use, and User Acceptance of Information Technology, dalam MIS Quarterly, 13(3). 319-340.

Gefen, D. (2000). E-Commerce: The Role of Familiarity and Trust, Omega: The International Journal of Management Science. 28(6). 725-737.

Gefen, D., Karahanna, E. \& Straub, D. W. (2003). Trust and TAM in Online Shopping: An Integrated Model. MIS Quarterly. 27(1), 51-90.

Hassanein, K., \& Head M. (2007). Manipulating Perceived Social Presence through the Web Interface and Its Impact on Attitude Towards Online Shopping. International Journal of Human-Computer Studies. 65(8), 689-708.

Igbaria, M., Juhani I. \& Hasan M. (1995). Why do Individuals use computer technology? A Finnish case study. Information \& Management. 29(5), 227-238.

Kotler, P. \& Kevin K. (2012). Marketing Management, 12 ed., New Jersey: Pearson Education.

Lin, C., Kwoting F. \& Chien-Chung, T. (2010). Predicting Consumer Repurchase Intentions to Shop Online. Journal of Computers. 5(10), 1527-1533.

Morgan, R. M. \& Shelby D. H. (1994). The Commitment-Trust Theory of Relationship Marketing. Journal of Marketing. 58(3), 20-38.

Rousseau, D. M., Sitkin, S. B., Burt, R. S. \& Camerer, C. (1998). Not so different after all: A cross-discipline view of trust. Academy of Management Review. 23(3), 394-404.

Rotter, J. A. (1967). A new scale for the measurement of interpersonal trust. Journal of Personality. 35(4), 651-665. 
Strauss, J. \& Raymond F. (2011). E-Marketing, Sixth edition. Pearson Prentice Hall.

Venkatesh, V. (2000). Determinants of perceived ease of use: integrating control, intrinsic motivation, and emotion into the technology acceptance model. Information Systems Research. 11(4), 342-365.

Wen, C., Victor R. P. \& Chenyan X. (2011) An integrated Model for Customer Online Repurchase Intention. Journal of Computer Information Systems. 52(1), 14-23.

Yousafzai, S. Y., Pallister, J. G. \& Foxall, G. R. (2003). A proposed model of e-trust for electronic banking, Technovation. 23 (11), 847-860. 